ñStepwise synthesis of RNA conjugates carrying peptide sequences for RNA interference studiesò. Aviñó, A., Ocampo, S. M., Caminal, C., Perales, J.C., Eritja, R. Mol. Divers., 13(3), 287-293 (2009). doi: 10.1007/s11030-009-9110-7

\title{
Stepwise synthesis of RNA conjugates carrying peptide sequences for RNA interference studies.
}

\author{
Anna Aviñó, Sandra M. Ocampo, Clara Caminal, José Carlos \\ Perales, \# and Ramon Eritja
}

Institute for Research in Biomedicine (IRB Barcelona), Institute for Advanced

Chemistry of Catalonia (IQAC-CSIC), Networking Centre on Bioengineering, Biomaterials and Nanomedicine (CIBER-BBN), Edifici Helix, Baldiri Reixac 15, E08028 Barcelona, Spain.

${ }^{\#}$ Dpt. of Ciencies Fisiológiques. School of Medicine. University of Barcelona (Campus Bellvitge). C/ Feixa Llarga, LâHospitalet de Llobregat. 08907 Barcelona, Spain

\begin{abstract}
Oligoribonucleotide conjugates carrying nuclear localization peptide sequences at the $3 \hat{\theta}$ end were prepared stepwise on a single support. The siRNA duplex carrying the nuclear localization peptide sequence at the 3 ôend of the passenger strand has similar inhibitory properties as those of unmodified or cholesterol-modified RNA duplexes.
\end{abstract}

KEYWORDS: siRNA, oligonucleotide-peptide conjugates, RNA interference, tumor necrosis factor, oligonucleotide synthesis. 


\section{INTRODUCTION}

In the last two decades new compounds comprising small synthetic nucleic acids have shown promising results as potential drugs $[1,2]$. In these cases, nucleic acids are used to inhibit a specific gene by blocking translation or transcription or by stimulating the degradation of a particular messenger RNA. Several strategies can be followed. In the antisense strategy, synthetic oligonucleotides complementary to the messenger RNA of a given gene are used to inhibit the translation of messenger RNA to protein [3, 4]. In the siRNA strategy, small RNA duplexes complementary to messenger RNA bind to a protein complex named RISC. The complex formed by the antisense or guide RNA strand and RISC catalyzes the efficient degradation of a specific messenger RNA, thereby lowering the amount of target protein $[5,6]$.

Some of the problems encountered during the development of nucleic acids as drugs entail the degradation of these by exonucleases under physiological conditions and their low uptake by cells. Most of the improvements in the design of nucleic acid derivatives aim to enhance stability to nuclease and improve cell uptake without affecting the hybridisation properties, which are vital for the efficient inhibitory properties of oligonucleotides. A large number of nucleic acid derivatives have been developed [5, 7]. The conjugation of lipids to oligonucleotides, such as cholesterol $[8,9]$, produces molecules with improved inhibitory properties [10, 11].

Oligonucleotide-peptide conjugates are chimeras of oligonucleotides and peptides which are produced to add some of the biological or biophysical properties of peptides to oligonucleotides. Reaction of oligonucleotides to polylysine [12], basic [13, 14], 
fusogenic $[15,16]$ and signal peptides $[17,18]$ has showed to produce new compounds with improved cellular uptake.

Peptide-oligodeoxynucleotide conjugates are prepared through distinct conjugation chemistries, which include either stable or cleavable linkages. In the post-synthetic conjugation approach, the two moieties are prepared independently on solid-phase and thiols and maleimido groups are especifically introduced to link the two molecules [17, 19]. In the stepwise approach, oligonucleotide-peptide conjugates are prepared by the addition of amino acids and nucleobases using solid-phase protocols on the same solid support $[16,20,21,22]$. In this case, the problem to be solved is the incompatibility of standard schemes of protection. For example, at the end of the solid-phase peptide synthesis a treatment with acid is usually required, which can lead to partial depurination of DNA. In the synthesis of oligonucleotide 3'-peptides, this effect can be prevented using Boc-protected amino acids with Fm or Fmoc groups for the protection of side chains, a base-labile linker and standard phosphoramidites [16, 20, 21].

In the RNA interference field, cationic cell-penetrating peptides such as TAT-peptide and penetratin, facilitate the cell uptake of siRNA [23-28]. A particulary successful result was obtained with a peptide derived from the glycoprotein of the rabies virus [23]. The incubation of this peptide, which carryies a polyarginine tail with siRNA, produced a complex that facilitates the delivery of siRNA to the central nervous system [23]. Most of the results obtained to date using peptides and siRNA were either not covalently linked to RNA or covalently linked by the post-synthetic conjugation method. Solid-phase protocols for the preparation of aminoacyl-tRNA fragments have been described [29, 30]; however to our knowledge there are no data on the preparation of RNA-peptide conjugates for RNA interference studies using the stepwise approach. 
Here we describe the stepwise synthesis of oligoribonucleotides carrying nuclear localization peptide sequences. Tumor necrosis factor (TNF- $\alpha$ ) was selected as a target. This protein is a major mediator of apoptosis as well as inflammation and immunity. Furthermore, TNF- $\alpha$ has been implicated in the pathogenesis of many human diseases and consequently the inhibition of this cytokine is of particular relevance.

\section{EXPERIMENTAL SECTION}

Abbreviations: ACN, acetonitrile; AmHex, 6-aminohexylsuccinyl; Boc, $t$ butoxycarbonyl; DBU, 1,8-diazabicyclo[5.4.0]undec-7-ene; DCM, dichloromethane; DIEA, $N, N$-diisopropylethylamine; DMF, $N, N$-dimethylformamide; DMT, 4, 40ิ dimethoxytrityl; Fm, fluorenylmethyl; Fmoc, fluorenylmethoxycarbonyl; PEG-PS, polyethyleneglycol-polystyrene; PyBOP, (benzotriazol-1yloxy)trispyrrolidinophosphonium hexafluorophosphate, TBDMS, $t$-butyldimethylsilyl; TEAA, triethylammonium acetate; TFA, trifluoroacetic acid.

\section{Oligonucleotides.}

The following RNA sequences were obtained from commercial sources (Sigma-Proligo, Dharmacon): sense or passenger scrambled 5ôCAGUCGCGUUUGCGACUGG-dTdT-3ô antisense or guide scrambled 5ôCCAGUCGCAAACGCGACUG-dT-dT-3ô antisense or guide anti-TNFa: 5ôGAGGCUGAGACAUAGGCAC-dT-dT-3ôand sense or passenger anti-TNFa: 5ôGUGCCUAUGUCUCAGCCUC-dT-dT-3ô RNA monomers in capital letters, dT represents 20̂deoxythymidine. The 30̂cholesterol passenger anti-TNFa: strand 5ô GUGCCUAUGUCUCAGCCUC-dT-dT-3ôcholesterol 
was prepared using the cholesterol-tetraethyleneglycol (TEG)-30̂CPG support from commercial sources (Glen Research). The anti-TNF $\alpha$ siRNA has been previously described to efficiently downregulate murine TNF $\alpha$ mRNA [31].

\section{Synthesis of oligonucleotide-peptide conjugates.}

Oligonucleotide-peptide conjugates were synthesized by the stepwise approach [32]. The following sequences were prepared I) 5'-uggauucgu-3ôp-O- $\left(\mathrm{CH}_{2}\right)_{5} \mathrm{CONH}_{-}{ }^{\mathrm{N}} \mathrm{Ala}-$ Lys-Lys-Lys-Lys-Leu-Asp-Lys ${ }^{\mathrm{C}}-\mathrm{CONH}-\left(\mathrm{CH}_{2}\right)_{6}-\mathrm{OH}$; II) 5' CUGAC-dT-ps-dT-3ôps-O$\left(\mathrm{CH}_{2}\right)_{5} \mathrm{CONH}^{-}{ }^{\mathrm{N}}$ Ala-Lys-Lys-Lys-Lys-Leu-Asp-Lys ${ }^{\mathrm{C}}-\mathrm{CONH}-\left(\mathrm{CH}_{2}\right)_{6}-\mathrm{OH}$; and III) 5'GUGCCUAUGUCUCAGCCUC-dT-dT-p-O- $\left(\mathrm{CH}_{2}\right)_{5} \mathrm{CONH}^{-}{ }^{\mathrm{N}}$ Ala-Lys-Lys-Lys-LysLeu-Asp-Lys ${ }^{\mathrm{C}}$-CONH- $\left(\mathrm{CH}_{2}\right)_{6}-\mathrm{OH}$. The following abbreviations are used: 20̂O-methylRNA monomers in low case, RNA monomers in capital letters, dT: 2ôdeoxythymidine, p: phosphate, ps: phosphorothioate linkages. Guanosine was protected with the dimethylaminomethylidene group, cytidine was protected with the acetyl group and adenosine with the benzoyl group. The $2 \hat{o} \mathrm{OH}$ protecting group for the RNA monomers was the $t$-butyldimethylsilyl (TBDMS) group. Boc-aminohexanol was reacted with succinic anhydride to form the corresponding hemisuccinate [20], which was reacted with amino functionalized PEG-PS support. Peptide chain was elongated manually in DMF using a 5-fold excess of amino acid Boc-protected amino acid and a 5-fold excess of PyBOP and a 10-fold excess of DIEA for $1 \mathrm{~h}$. Lysine was protected with the Fmoc group and aspartic acid was protected with the Fm group. Once the peptide sequence was completed, the resulting support was reacted with $p$-nitrophenyl 6-(4,4'dimethoxytrityloxy)hexanoate [20]. The addition of this building block introduces an hydroxyl group to the existing peptide. This hydroxyl group is required for the assembly of the oligonucleotide. The linker was coupled to the peptide-support using PyBOP and 
DIEA as described above. The unreacted amino groups of the resulting support were blocked with acetic anhydride and DIEA. Oligonucleotides were prepared on a DNA synthesizer (Applied Biosystems 3400) using 2-cyanoethyl phosphoramidites. The following solutions were used: $0.4 \mathrm{M} \quad 1 H$-tetrazol in $\mathrm{ACN}$ (activation); 3\% trichloroacetic acid in DCM (detritylation), acetic anhydride / pyridine /tetrahydrofurane (1: 1: 8) (capping A), $10 \% \mathrm{~N}$-methylimidazole in tetrahydrofurane (capping B), $0.01 \mathrm{M}$ iodine in tetrahydrofurane/ pyridine /water (7:2:1) (oxidation). The phosphoramidites were dissolved in dry DCM $(0.1 \mathrm{M})$. A modified cycle was used: Coupling time was increased to $5 \mathrm{~min}$, capping and oxidation times to $1 \mathrm{~min}$, and detritylation time to 2 $\min (4 \times 30 \mathrm{~s})$. In the synthesis of the $2 \hat{o} O$-methyl-RNA sequence I, the last DMTprotecting group was not removed. In the RNA sequences II and III, the last DMT group was removed because the DMT is partially lost during the fluoride treatment. The average coupling yield was around $97-98 \%$ per step for RNA monomers and $99 \%$ for 2ô $O$-methyl-RNA monomers. The solid supports containing the oligonucleotidepeptide conjugates were washed with acetonitrile, treated with a $0.5 \mathrm{M}$ DBU solution in ACN for 5 min, washed with ACN, and dried. The resulting supports were then treated with concentrated aqueous ammonia-ethanol (3:1) for $1 \mathrm{~h}$ at $55^{\circ} \mathrm{C}$. After filtration of the solid supports, the supports were washed with ethanol and the combined solutions were evaporated to dryness. Sequences II and III were treated with $0.15 \mathrm{ml}$ of triethylamine.tris(hydrofluoride) / triethylamine / $N$-methylpyrrolidone (4:3:6) for $2.5 \mathrm{~h}$ at $65^{\circ} \mathrm{C}$ to remove the TBDMS groups. The reactions were stopped by adding $0.3 \mathrm{ml}$ of isopropoxytrimethylsilane and $0.75 \mathrm{ml}$ of ether. The resulting mixtures were stirred and cooled at $4{ }^{\circ} \mathrm{C}$. A precipitate was formed which was then centrifuged at $7000 \mathrm{rpm}$ for 5 min at $4{ }^{\circ} \mathrm{C}$. The precipitates were washed with ether and centrifuged again. The residues were dissolved in water and the conjugates were purified by HPLC. Column: 
Nucleosil $120-10 \mathrm{C}_{18}(250 \times 4 \mathrm{~mm}) ; 20$ min linear gradient from $15 \%$ to $80 \% \mathrm{~B}$ and 5 $\min 80 \%$ B (DMT-on conditions, sequence I); 20 min linear gradient from $0 \%$ to $50 \%$ B (DMT-off conditions, sequences II and III); flow rate $3 \mathrm{ml} / \mathrm{min}$; solution A was $5 \%$ $\mathrm{ACN}$ in $0.1 \mathrm{M}$ aqueous TEAA and $\mathrm{B} 70 \% \mathrm{ACN}$ in $0.1 \mathrm{M}$ aqueous TEAA. The purified products were analyzed by MALDI-TOF mass spectrometry. Sequence I $[M]=4161.0$ (expected $M=4165.3)$. Yield $(0.5 \mu \mathrm{mol}$ scale synthesis) was $12 \mathrm{OD}$ units at $260 \mathrm{~nm}$ (120 nmol, 24\%). Sequence II $[\mathrm{M}]=3376.5$ (expected $\mathrm{M}=3377.2)$. Yield $(0.5 \mu \mathrm{mol}$ scale synthesis) was $1.7 \mathrm{OD}$ units at $260 \mathrm{~nm}(25 \mathrm{nmol}, 5 \%)$. Sequence III $\left[\mathrm{M}+\mathrm{Na}^{+}\right]=$ 7785.7 (expected $M=7766.6)$. Yield $(0.2 \mu$ mol scale synthesis) was 2.1 OD units at 260 $\mathrm{nm}(10 \mathrm{nmol}, 5 \%)$. The purified conjugates were judged to be homogeneous (purity $>90 \%$ ) by analytical HPLC and denaturing polyacrylamide gel electrophoresis.

Analytical HPLC was performed using XBridge ${ }^{\mathrm{TM}}$ OST C18 (Waters), $2.5 \mu \mathrm{m}, 4.6$ x 50 mm column using a 10 min linear gradient from $0 \%$ to $35 \% \mathrm{~B}$, flow rate $1 \mathrm{ml} / \mathrm{min}$; solution $\mathrm{A}$ was $5 \% \mathrm{ACN}$ in $0.1 \mathrm{M}$ aqueous TEAA and $\mathrm{B} 70 \% \mathrm{ACN}$ in $0.1 \mathrm{M}$ aqueous TEAA.

Denaturing polyacrylamide gel electrophoreses were performed in a SE-600 Hoefer Scientific apparatus. The gels (8 M urea, 20\%, acrylamide/ bisacrylamide ratio 19:1), 14 x $16 \times 0.1 \mathrm{~cm}$ in size were run for $5 \mathrm{~h}$ at $400 \mathrm{~V}$. Three micrograms of RNA were loaded. The gel was stainned with Stains-all (Sigma).

MALDI-TOF spectra were performed using a Perseptive Voyager DETMRP mass spectrometer, equipped with nitrogen laser at $337 \mathrm{~nm}$ using a $3 \mathrm{~ns}$ pulse. The matrix used contained 2,4,6-trihydroxyacetophenone (THAP, $10 \mathrm{mg} / \mathrm{ml}$ in ACN/ water 1:1) and ammonium citrate $(50 \mathrm{mg} / \mathrm{ml}$ in water).

\section{Melting experiments.}


Oligonucleotides (1 عM each) were dissolved in $100 \mathrm{mM}$ potassium acetate, $2 \mathrm{mM}$ magnesium acatate, and $30 \mathrm{mM}$ HEPES-KOH at $\mathrm{pH}$ 7.4. The solutions were heated to $90{ }^{\circ} \mathrm{C}$, allowed to cool slowly to room temperature, and stored at $4^{\circ} \mathrm{C}$ until UV was measured. UV absorption spectra and melting experiments (absorbance vs. temperature) were recorded in Teflon-stoppered 1-cm path length quartz cells using a spectrophotometer, with a temperature controller and a programmed temperature increase rate of $1{ }^{\circ} \mathrm{C} / \mathrm{min}$. Melting curves were run in duplicate at $260 \mathrm{~nm}$. In all cases the complexes displayed sharp, apparently two-state transitions. The data were analyzed by the denaturation curve-processing program.

Cell culture, transfection and cellular assays.

HeLa cells were cultured under standard conditions $\left(37^{\circ} \mathrm{C}, 5 \% \mathrm{CO}_{2}\right.$, Dulbeccoôs Modified Eagle Medium, 10\% fetal bovine serum, 2mM L-glutamine, supplemented with penicillin $(100 \mathrm{U} / \mathrm{ml})$ and streptomycin $(100 \mathrm{mg} / \mathrm{ml})$. All experiments were conducted at 40-60\% confluence. HeLa cells were transfected with $250 \mathrm{ng}$ of murine expressing the TNF- $\alpha$ plasmid using lipofectin (Invitrogen), following the manufacturerô instructions. One hour after transfection, m-TNF- $\alpha$ expressing HeLa cells were transfected with 50nM of siRNA (5ôGUGCCUAUGUCUCAGCCUC-dTdT-3ô / 5ô GAGGCUGAGACAUAGGCAC-dT-dT-3ô [31]) against TNF- $\alpha$, using oligofectamine (Invitrogen). The TNF- $\alpha$ concentration was determined from cell culture supernatant by enzyme-linked immunoabsorbent assay kit (Bender MedSystems) following the manufacturerôs instructions.

The unmodified siRNA duplex produced $87 \%$ inhibition of TNF- $\alpha$ compared with the scrambled siRNA sequence, cholesterol-modified siRNA produced $81 \%$ inhibition and nucleoplasmine-modified siRNA produced 89\% inhibition (Fig. 3). 


\section{RESULTS AND DISCUSSION}

\section{Synthesis of oligonucleotide-peptide conjugates}

Oligonucleotide-peptide conjugates carrying the nucleoplasmine nuclear localization sequence (AKKKKLDK) were synthesized following the stepwise approach. Polyethylenglycol-polystyrene (PEG-PS) was selected as solid support since it gave the best results for the coupling of amino acids and nucleoside phosphoramidites [20, 32, 33]. Scheme 1 shows the outline of the synthesis of the oligonucleotide-peptide conjugates on the same support $[20,32,33]$. To avoid the use of strong acids in the presence of the oligonucleotide, the peptide part was first synthesized using the acidlabile Boc group to protect the $\alpha$-amino function. The protective groups of the side chain of the amino acids (Fmoc for Lys and Fm for Asp) and the linker of the first aminoacid to the support were base-labile so that they would be removed at the same time as the protective groups of the nucleobases. To this end, the 6-aminohexylsuccinyl (AmHex, [34]) was used. This linker yields the peptide with an aminohexylamide group at the C-terminal.

Once the peptide had been synthesized, the p-nitrophenyl 6-(4,4'dimethoxytrityloxy)hexanoate spacer molecule [20] was added to connect the oligonucleotide. This molecule introduces an hydroxyl group protected by a DMT group at the $N$-terminal position of the peptide. After the addition of the linker, oligonucleotide synthesis was studied in a small 20̂O-methyl-RNA sequence (I: 5'uggauucgu-3ôp-O- $\left(\mathrm{CH}_{2}\right)_{5} \mathrm{CONH}^{-}{ }^{\mathrm{N}} \mathrm{AKKKKLDK}{ }^{\mathrm{C}}-\mathrm{CONH}-$ hexyl-OH) using a slightly modified synthesis cycle and $1 H$-tetrazole activation. The average coupling yield was around $99 \%$ per step. The last DMT group was not removed in order to facilitate the 
purification of the conjugate by reversed phase HPLC (Fig. 1). The desired compound was purified in good yield and was characterized by mass spectrometry.

We next studied the assembly of a short RNA sequence (II: 5' CUGAC-dT-ps-dT-3ôps$\mathrm{O}-\left(\mathrm{CH}_{2}\right)_{5} \mathrm{CONH}-{ }^{\mathrm{N}} \mathrm{AKKKKLDK}{ }^{\mathrm{C}}-\mathrm{CONH}-$ hexyl-OH$)$. This sequence contains 5 ribonucleotides, 2 thymidine residues (dT) and 2 phosphorothioate (ps) linkages at the 3ôend. These are usual modifications in RNA interference studies. RNA monomers were protected with the $t$-butyldimethylsilyl (TBDMS) group. The same modified cycle for the synthesis of the $2 \hat{o} O$-methyl-RNA conjugate was used. In this case the coupling yield was slightly lower $97-98 \%$ as a result of steric hindrance of the TBDMS. The last DMT group was removed before deprotection because partial loss was detected during fluoride treament. For cleavage and deprotection, three consecutive treatments were applied: first a 0.5 M DBU solution in ACN; second, concentrate aqueous ammoniaethanol 3:1 at $55^{\circ} \mathrm{C}$, and third, triethylamine tris(hydrofluoride) in $N$-methylpyrrolidone at $65^{\circ} \mathrm{C}$. HPLC purification gave a major product that had the mass expected. The yield obtained after purification (5\%) was lower than that achieved in the synthesis of the $2 \hat{\Theta}$ $O$-methyl-RNA conjugate (24\%). This difference is attributed to the manipulation steps followed when removing the TBDMS groups. In order to eliminate the excess of fluoride, precipitation of the conjugate with ether is required and this may lower the recovery of the desired conjugate as a result of the small size of the oligomer ( $7 \mathrm{mer}$ ).

Finally, the 21mer sequence III) 5'- GUGCCUAUGUCUCAGCCUC-dT-dT-p-O$\left(\mathrm{CH}_{2}\right)_{5} \mathrm{CONH}-{ }^{\mathrm{N}} \mathrm{AKKKKLDK}{ }^{\mathrm{C}}-\mathrm{CONH}-\mathrm{hexyl}-\mathrm{OH}$ was assembled using the same protocol described for sequence II. In this case the desired conjugate was isolated in a $5 \%$ after HPLC purification (Fig. 2). The yield of the 21 mer obtained after purification was the same as that of the 7 mer but the former was three times longer, thereby indicating a more efficient recovery of the longer conjugate. The purified conjugate was 
analyzed by HPLC and polyacrylamide gel electrophoresis and characterized by MADITOF mass spectrometry.

We examined the effect of the peptide on siRNA duplex stability. The thermal stability of the modified and unmodified duplexes was measured in $100 \mathrm{mM}$ potassium acetate, $2 \mathrm{mM}$ magnesium acetate, and $30 \mathrm{mM}$ HEPES-KOH at $\mathrm{pH}$ 7.4. The melting temperature $(\mathrm{Tm})$ of the duplex containing nucleoplasmine was $83.8^{\circ} \mathrm{C}$ while the $\mathrm{Tm}$ of the unmodified duplex was $83.5^{\circ} \mathrm{C}$. A slighty higher stabilization of the duplex has been described for this peptide on DNA duplexes [32] and it has been attributed to a possible interaction between lysine side chain and DNA phosphates. In the present study two unpaired thymidines separated the peptide from the DNA backbone, therefore it is reasonable to expect no differences between modified and unmodified duplexes.

Inhibition of TNF- $\alpha$.

Oligonucleotide-peptide sequence III was annealed with equimolar amounts of the unmodified guide strand and the resulting duplex was used to inhibit the expression of the TNF- $\alpha$ gene. HeLa cells were transfected first with plasmid expressing murine TNF- $\alpha$ using lipofectin and $1 \mathrm{~h}$ later were co-transfected with the siRNA duplex (50 $\mathrm{nM}$ ) using oligofectamine. After $24 \mathrm{~h}$ the amount of TNF- $\alpha$ produced by the cells was analyzed by enzyme-linked immunoabsorbent assay (ELISA). Fig. 3 shows the amount of TNF- $\alpha$ produced after $24 \mathrm{~h}$ of transfection of 50nM siRNA unmodified duplexes. Modified and unmodified siRNA against TNF- $\alpha$ produced an $80-90 \%$ inhibition of the production of TNF- $\alpha$ compared with the scrambled control siRNA duplex. These results indicate that the introduction of the peptide sequence at the 3 ôend of the passenger strand of an RNA duplex does not affect the inhibitory properties of the 
resulting siRNA duplex in HeLa cells. Further work is required to determine whether the presence of the peptide improves the delivery of the siRNA into cells.

In conclusion, we have demonstrated that RNA carrying nucleosplasmine peptide can be synthesized using the stepwise approach. siRNA duplexes covalently linked to the nucleoplasmine peptide can be efficiently delivered to HeLa cells and these conjugates enter the RNAi pathway to silence gene expression as efficiently as unmodified and 30̂ cholesterol modified siRNA duplexes.

Acknowledgements. This work was supported by the Spanish Ministry of Education (grants NAN2004-09415-C05-03, BFU2007-63287, BFU2006-02802), the Generalitat de Catalunya (2005/SGR/00693) and the Instituto de Salud Carlos III (CIBER-BNN, CB06_01_0019).

\section{References.}

1. Braasch DA, Corey DR (2002) Novel antisense and peptide nucleic acid strategies for controlling gene expression. Biochemistry 41: 4503-4513.

2. Fabani MM, Turner JJ, Gait MJ (2006) Oligonucleotide analogs as antiviral agents. Curr Opin Mol Ther 8: 108-114.

3. Aboul-Fadl T (2005) Antisense oligonucleotides: the state of the art. Curr Med Chem 12: $2193-2214$.

4. Chan JH, Lim S, Wong WS (2006) Antisense oligonucleotides: from design to therapeutic application. Clin Exp Pharmacol Physiol 33: 533-540. 
5. Brumcot D, Manoharan M, Koteliansky V, Sah DW (2006) RNAi therapeutics: a potential new class of pharmaceutical drugs. Nat Chem Biol 2: 711-719.

6. De Fougerolles A, Manoharan M, Meyers R, Vornlocher HP (2005) RNA interference in vivo: toward synthetic small inhibitory RNA-based therapeutics Methods Enzymol 392: 278-296.

7. Urban E, Noe CR (2003) Structural modifications of antisense oligonucleotides. Farmaco 58: 243-258.

8. Gryaznov SM, Lloyd DH (1993) Modulation of oligonucleotide duplex and triplex stability via hydrophobic interactions. Nucleic Acids Res 21: 5909-5915.

9. Zelphati O, Wagner E, Leserman L (1994) Synthesis and HIV activity of thiocholesteryl-coupled phosphodiester antisense oligonucleotides incorporated into immunoliposomes. Antiviral Res 25: 13-25.

10. LeDoan T, Etore F, Tenu JP, Letourneux Y, Agrawal S (1999) Cell binding, uptake and cytosol partition of HIV anti-gag phosphodiester oligonucleotides 3ôlinked to cholesterol derivatives in macrophages. Bioorg Med Chem 7: 2263-2269.

11. Soutschek J, Akinc A, Bramlage B, Chavisse K, Constien R, Donoghue M, Elbashir S, Geick A, Hadwiger P, Harborth J, John M, Kesavan V, Lavine G, Pandey RK, Racie T, Rajeev KG, Röhl I, Toudjarska I, Wang G, Wuschko S, Bumcrot D, Koteliansky V, Limmer S, Manoharan M, Vornlocher HP (2004) Therapeutic silencing of an endogenous gene by systemic administration of modified siRNAs. Nature 432: 173 178.

12. Lemaitre M, Bayard B, LeBleu B (1987) Specific antiviral activity of poly (Llysine)-conjugated oligodeoxynucleotide sequence complementary to vesicular stomatitis virus N protein mRNA initiation site. Proc Natl Acad Sci USA 84: 648-652. 
13. Vivès E, LeBleu B (1997) Selective coupling of a highly basic peptide to an oligonucleotide. Tetrahedron Lett 38: 1183-1186.

14. Sazani P, Gemignani F, Kang SH, Maier MA, Manoharan M, Persmark M, Bortner

D, Bortner D, Kole R (2002) Systemically delivered antisense oligomers upregulate gene expression in mouse tissues. Nature Biotech 20: 1228-1233.

15. Bongartz JP, Aubertin AM, Milhaud, PG, Lebleu B (1994) Improved biological activity of antisense oligonucleotides conjugated to a fusogenic peptide. Nucleic Acids Res 22: 4681-4688.

16. Soukchareun S, Tregear GW, Haralambidis J (1995) Preparation and characterization of antisense oligonucleotide-peptide hybrids containing viral fusion peptides. Bioconjug Chem 6: 43-53.

17. Arar K, Monsigny M, Mayer R (1993) Synthesis of oligonucleotide-peptide conjugates containing a KDEL signal sequence. Tetrahedron Lett 34: 8087-8090.

18. Zanta MA, Belguise-Valladier P, Behr JP (1999) Gene delivery: a single nuclear localization signal peptide is sufficient to carry DNA to the cell nucleus. Proc Natl Acad Sci USA 96: 91-96.

19. Eritja R, Pons A, Escarceller M, Giralt E, Albericio F (1991) Synthesis of defined peptide-oligonucleotide hybrids containing a nuclear transport signal sequence. Tetrahedron 47: 4113-4120.

20. de la Torre BG, Aviñó A, Tarrasón G, Piulats J, Albericio F, Eritja R (1994) Stepwise solid-phase synthesis of oligonucleotide-peptide hybrids. Tetrahedron Lett 35: 2733-2736.

21. Robles J, Maseda M, Beltrán M, Concernau M, Pedroso E, Grandas A (1997) Synthesis and enzymatic stability of phosphodiester-linked peptide-oligonucleotide hybrids. Bioconjug Chem 8: 785-788. 
22. Antopolsky M, Azhayeva E, Tengvall U. Azhayev A (2002) Towards a general method for the stepwise solid-phase synthesis of peptide-oligonucleotide conjugates. Tetrahedron Lett 43: 527-530.

23. Kumar P, Wu H, McBride JL, Jung KE, Kim MH, Davidson BL, Lee SK, Shankar P, Manjunath N (2007) Transvascular delivery of small interfering RNA to the central nervous system. Nature 448: 39-43.

24. Chiu YL, Ali A, Chu CY, Cao H, Rana TM (2004) Visualizing a correlation between siRNA localization, cellular uptake, and RNAi in living cells. Chem Biol 11: 1165-1175.

25. Moschos SA, Williams AE, Linsay MA (2007) Cell-penetrating-peptide-mediated siRNA lung delivery Biochem Soc Trans 35: 807-810.

26. Turner JJ, Jones S, Fabani MM, Ivanova G, Arzumanov AA, Gait MJ (2007) RNA targeting with peptide conjugates of oligonucleotides, siRNA and PNA. Blood Cells Mol Diseases 38: 1-7.

27. Juliano RL (2005) Peptide-oligonucleotide conjugates for the delivery of antisense and siRNA. Curr Opin Mol Ther 7: 132-136.

28. Muratouska A, Eccies MR (2004) Conjugate for efficient delivery of short interfering RNA (siRNA) into mammalian cells. FEBS Lett 558: 63-68.

29. Botta O, Strazewski, P (1999) Synthesis of an alanyl adenosine analog. Nucleosides Nucleotides 18:721-723.

30. Nguyen-Trung, NQ, Terenzi S, Scherer G, Strazewski P (2003) High-yield immobilization of a puromycin analogue for the solid support synthesis of aminoacyltRNA fragments. Org Lett 5: 2603-2606.

31. Sorensen DR, Leirdal M, Sioud MJ (2003) Gene silencing by systemic delivery of synthetic siRNA in adult mice. J Mol Biol 327: 761-766. 
32. de la Torre BG, Albericio F, Saison-Behmoaras E, Bachi A, Eritja R (1999) Synthesis and binding properties of oligonucleotides carrying nuclear localization sequences. Bioconjug Chem 10: 1005-1012.

33. Frieden M, Aviñó A, Tarrasón G, Escorihuela M, Piulats J, Eritja R (2004) Synthesis of oligonucleotide-peptide conjugates carrying the c-myc peptide epitope as recognition system. Chem Biodiv 1: 930-938.

34. Will DW, Breipohl G, Langner D, Knolle G, Uhlmann E (1995) The synthesis of polyamide nucleic acids using a novel monomethoxytrityl protecting-group strategy. Tetrahedron 51: 12069-12082. 
Scheme 1. Outline of the synthesis of oligonucleotide-3ôpeptide conjugates.

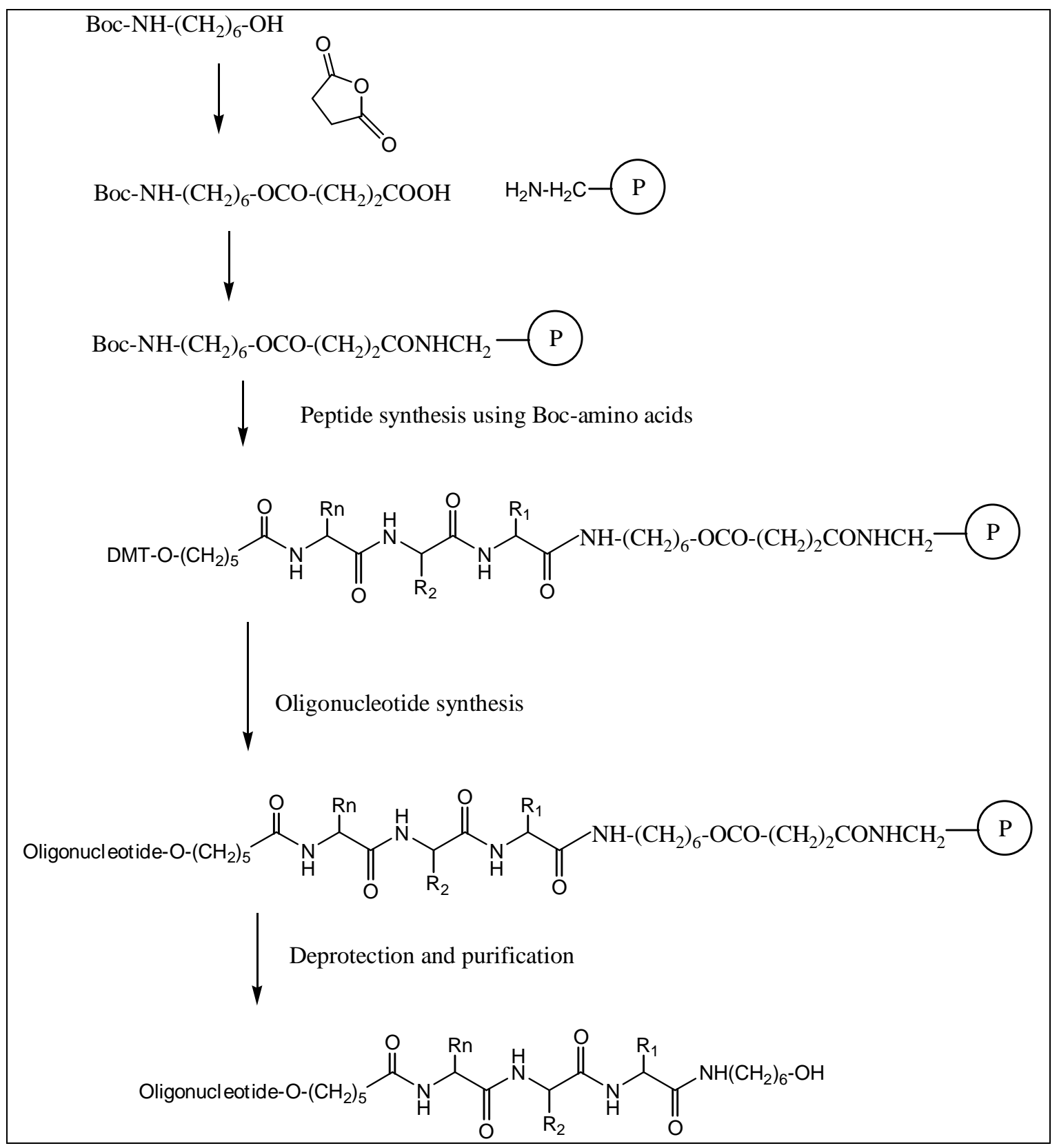


Fig. 1. HPLC profile of the product obtained after the synthesis of the nucleoplasmineoligo-2ôO-methyl(ribonucleotide) conjugate I (5'-uggauucgu-3ôp-O- $\left(\mathrm{CH}_{2}\right)_{5} \mathrm{CONH}$ ${ }^{\mathrm{N}}$ Ala-Lys-Lys-Lys-Lys-Leu-Asp-Lys $\left.{ }^{\mathrm{C}}-\mathrm{CONH}-\left(\mathrm{CH}_{2}\right)_{6}-\mathrm{OH}\right)$ using DMT-on conditions. Product eluting at $12 \mathrm{~min}$ is the desired conjugate. Inset: analytical HPLC of the purified product (see experimental section).

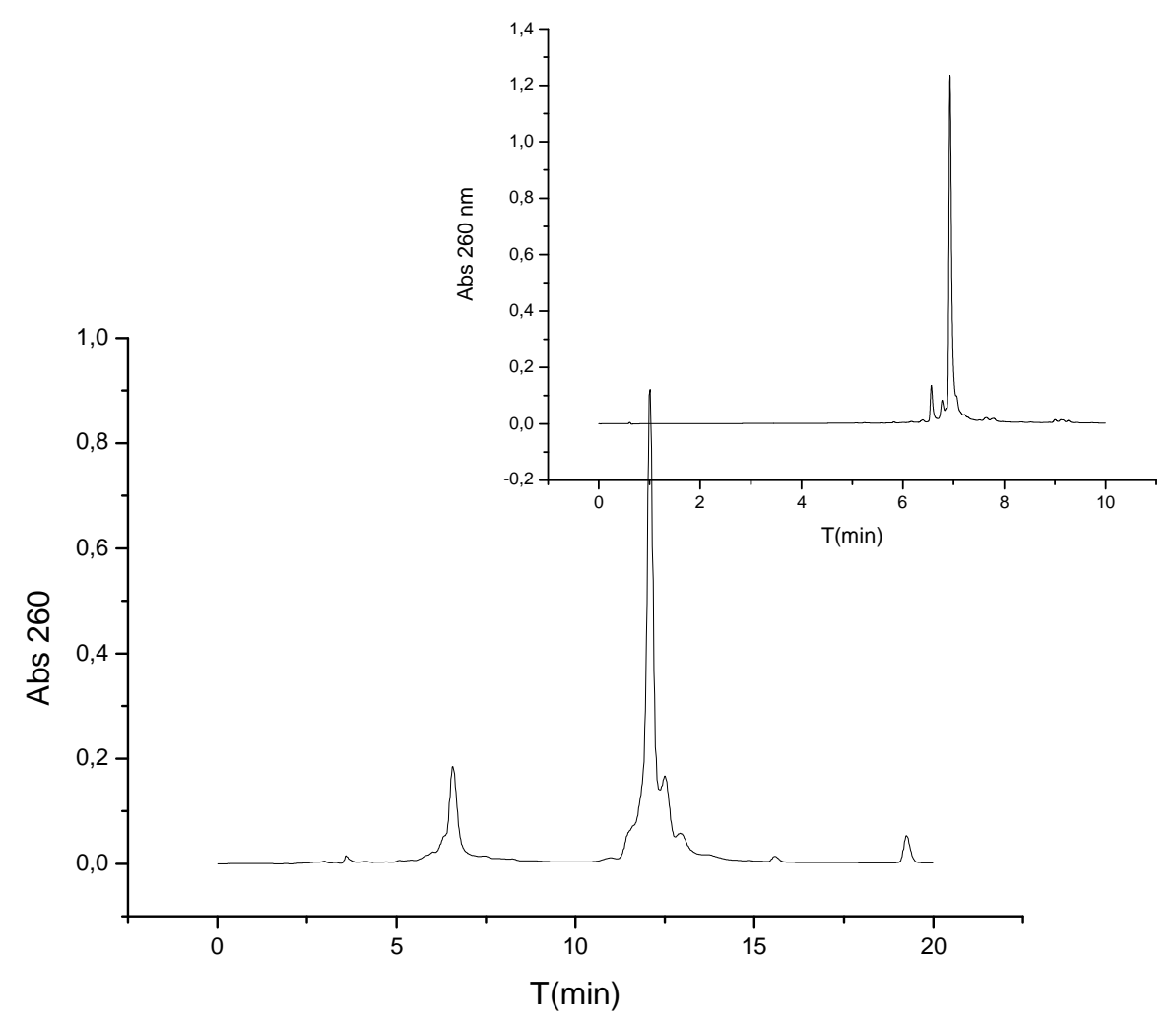


Fig. 2. HPLC profile of the product obtained after the synthesis of the nucleoplasmineoligoribonucleotide conjugate III (5'- GUGCCUAUGUCUCAGCCUC-dT-dT-p-O$\left(\mathrm{CH}_{2}\right)_{5} \mathrm{CONH}-{ }^{\mathrm{N}}$ Ala-Lys-Lys-Lys-Lys-Leu-Asp-Lys $\left.{ }^{\mathrm{C}}-\mathrm{CONH}-\left(\mathrm{CH}_{2}\right)_{6}-\mathrm{OH}\right)$ using DMToff conditions. Product eluting at $10 \mathrm{~min}$ is the desired conjugate. Inset: analytical HPLC of the purified product (see experimental section).

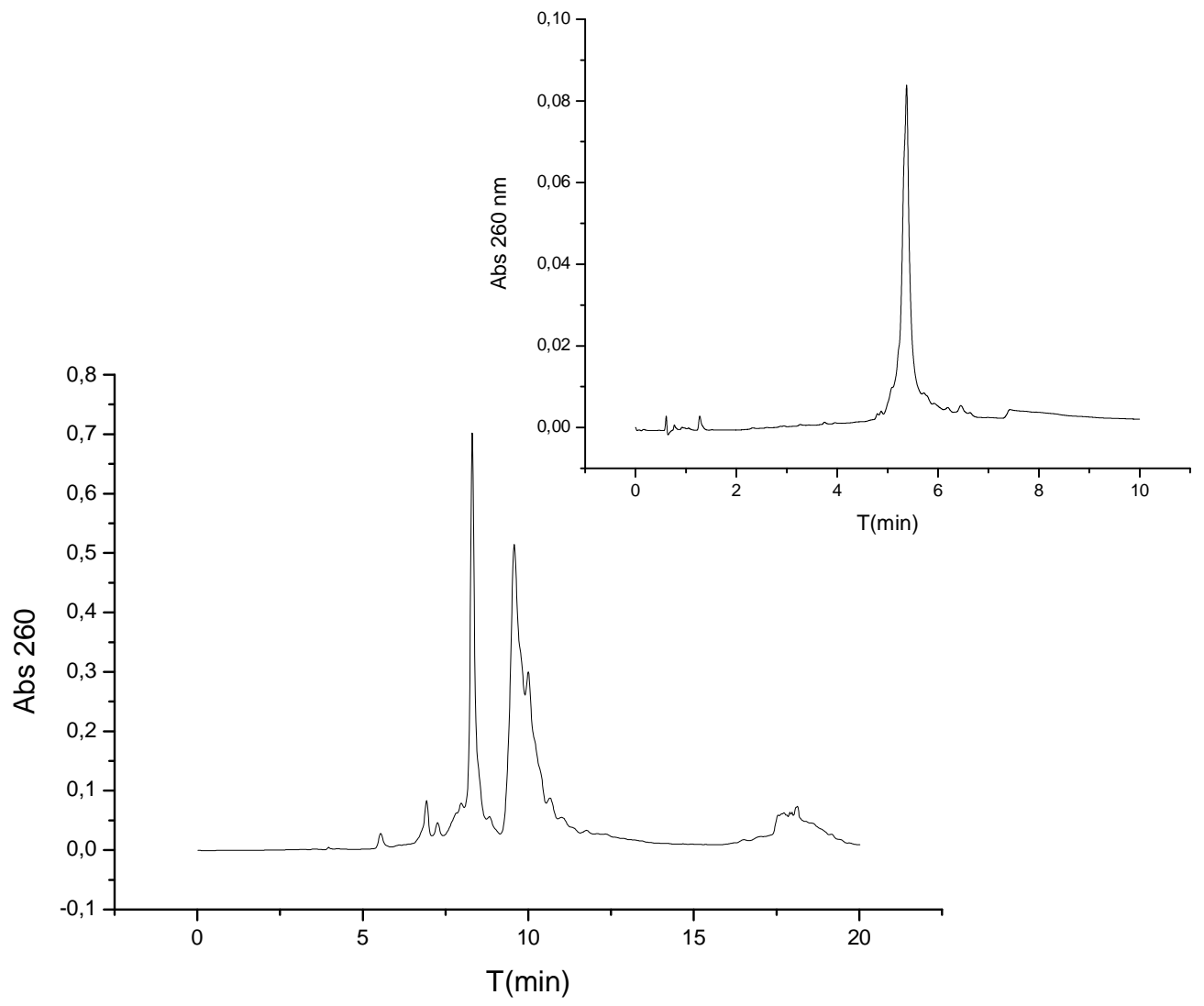


Fig. 3. Potency in vivo of several chemically modified siRNAs against TNF- $\alpha$. Amount of TNF- $\alpha$ produced after $24 \mathrm{~h}$ of transfection of 50nM siRNA unmodified duplex (Unmodified), $50 \mathrm{nM}$ of the same siRNA duplex carrying a cholesterol molecule at the 3ôend of the passenger strand (Cholesterol), $50 \mathrm{nM}$ of the same siRNA duplex carrying the nucleoplasmine peptide at the 3ôend of the passenger strand (sequence III, Nucleoplasmine) and $50 \mathrm{nM}$ of a scrambled RNA duplex control sequence (Scr). Error bars represent the s.d of the mean. Statistical analysis was by ANOVA with Bonferroni post-test, one-tailed. $* * *$ or \#\#\# $\mathrm{P}<0.001$ compared with scrambled siRNA.

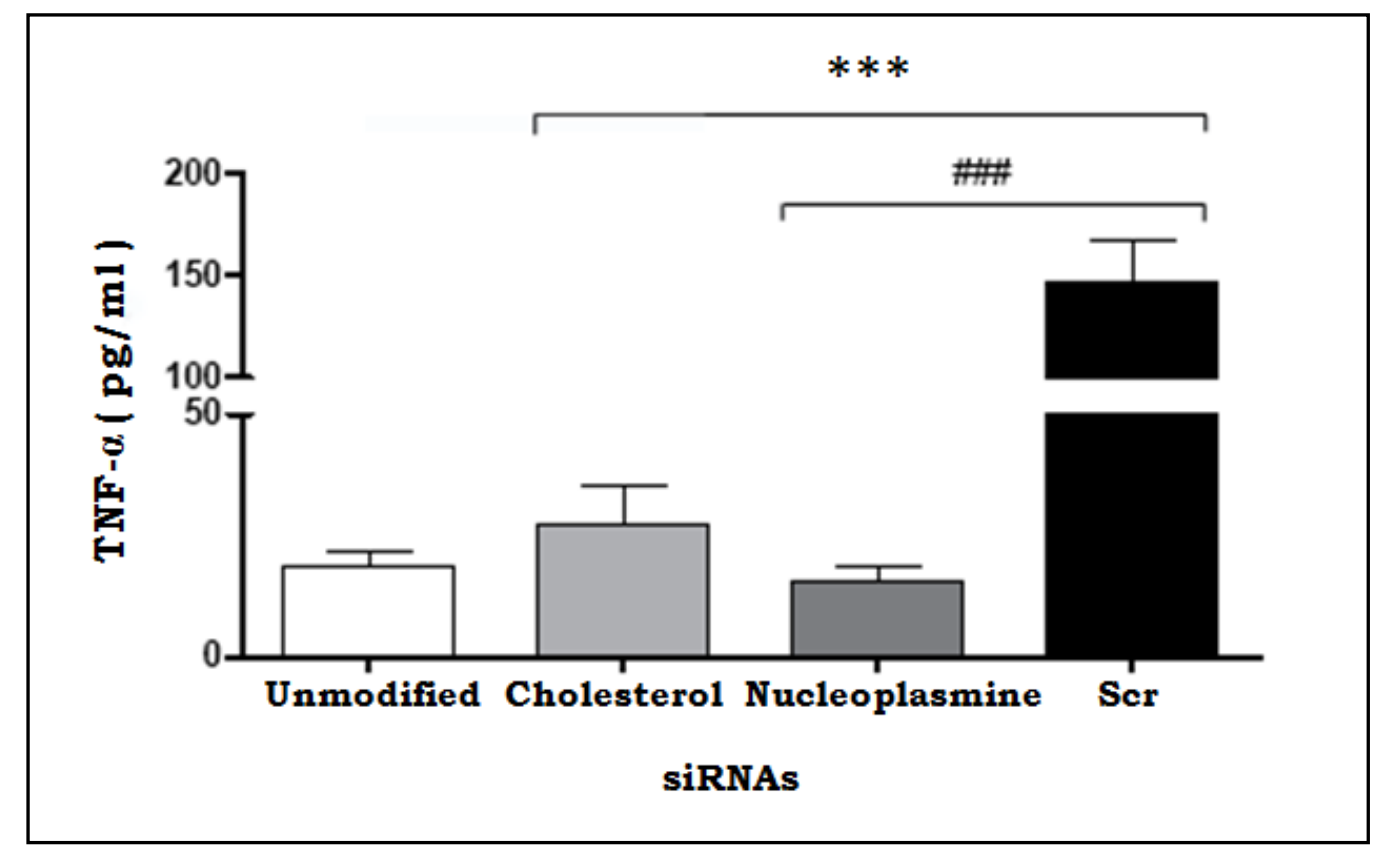

